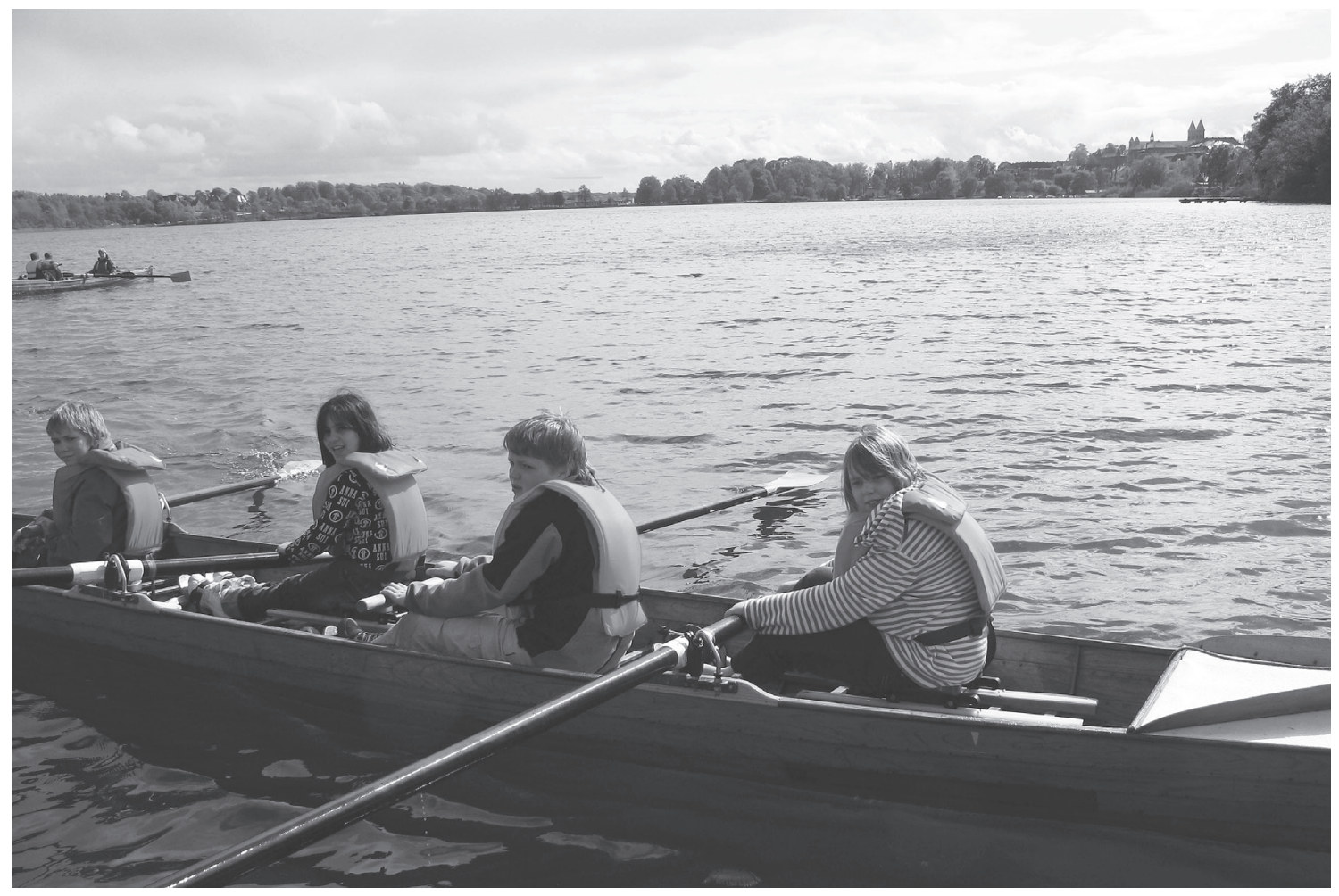

I 2006 udmøntedes et satspuljeforlig i en allokering af 40 mio. kr. til "idrætsprojekter for vanskeligt stillede, overvægtige børn". Billedet og indgår i Annette Michelsen la Cours Ph.d.-afhandling fra 2010 om Idrætsforeningernes velfærdspotentiale. En sociologisk analyse af sammenhængen mellem velfærdspolitik, social kapital og socialt entreprenørskab i 21 idrætsprojekter for vanskeligt stillede børn. (Fotograf Lone Simonsen)

\title{
Forsøgs- og udviklingsprogrammer i dansk idratspolitik
}




\section{INDLEDNING}

I flere årtier bestod idrætspolitikken i Danmark primært af to spor. For det første den kommunale støtte til idrætsforeningerne samt anlæggelse og drift af idrætsfaciliteter, der stilles gratis til rådighed for foreningerne (eller kommunens refusion af hovedparten af foreningernes udgifter til benyttelse af egne eller lejede lokaler). For det andet statsstøtten til de frivillige idrætsorganisationer (DIF, DGI, DFIF m.fl.) og en række statslige institutioner (Team Danmark, Anti-Doping Danmark m.fl.) fra Dansk Tipstjenestes overskud (i dag Danske Spil) (Ibsen \& Eichberg 2012).

Selvom lovgivningen bag de to hovedspor $\mathrm{i}$ idrætspolitikken er revideret mange gange, siden Tipsloven blev vedtaget i 1948 (i dag 'Lov om visse spil, lotterier og væddemål'), og vedtagelsen af Fritidsloven (i dag Folkeoplysningsloven) tyve år senere, er de grundlæggende principper for, hvordan idrætsforeninger og idrætsorganisationer støttes næsten de samme: Lovbestemt offentlig støtte til frivillige foreninger og organisationer uden specifikke krav til midlernes anvendelse.

De seneste knap tyve år er disse to hovedspor i idrætspolitikken imidlertid blevet suppleret af et sidespor, der ganske vist ikke har større betydning i økonomisk forstand, men alligevel har så stor opmærksomhed, at både idrætsorganisationer, kommuner og en del foreninger i høj grad indretter sig derefter. Det drejer sig om forsøgsog udviklingsprogrammer og -puljer.

Forsøgs- og udviklingsprogrammer kan defineres som

"lovgivningsmæssigt udbundne, centralpolitisk besluttede og forvaltede midler, der ved siden af de almindelige bloktilskud fordeles til amter, kommuner, frivillige organisationer, virksomheder m.fl. efter særskilt aftalte principper" (Anker et al. 2001).
Denne artikel tager sigte på at belyse denne del af dansk idrætspolitik i et historisk-sociologisk perspektiv. Først analyseres den historiske udvikling i denne del af idrætspolitikken. Dernæst analyseres og diskuteres, hvilken betydning de mange puljer og projekter har haft. Og til sidst diskuteres svaghederne men også potentialerne i den følgeforskning, som er en integreret del af pulje- og projekt-politikken.

\section{FORSøGS- OG UDVIKLINGSPROGRAMMER I DANMARK}

Udbygningen af velfærdsstaten igennem 1950' erne og 1960'erne var præget af en forestilling om, at samfundets problemer kunne løses ved statslig planlægning under inddragelse af den nyeste forskning og ekspertise på området. Oprettelsen af Socialforskningsinstituttet (i dag Det Nationale Forskningscenter for Velfærd) var bl.a. et led i denne forestilling.

Igennem 1960'erne opstod der langsomt en reaktion på denne 'top down politik' præget af centralisme og ekspertstyring. I første omgang i det civile samfund. De første projekter - primært med støtte fra private fonde - så dagens lys i slutningen af 1960'erne, og de voksede i antal igennem 1970'erne. I begyndelsen talte man ikke om "forsøg" men om "alternativer". 1960'erne og 1970'erne var på mange områder “alternativernes årtier" med alternative samlivsformer, nye behandlingsformer (for eksempel for stofmisbrugere), ledelsesformer (bl.a. kollektive ledelsesformer), produktionsformer, skoleformer (for eksempel lilleskolerne), pædagogik (bl.a. arbejds- og projektpædagogik), boformer (eksempelvis forskellige former for beboer- og aktivitetshuse) og samfundsformer, mv. (Hegland 1990).

Disse 'alternativer' havde på mange områder de samme kendetegn og problemer. De opstod 
typisk lokalt og forholdsvis spontant som en reaktion mod det bestående; de var ikke organiseret "fra oven" eller på baggrund af store teoretiske og strategiske overvejelser); de fik hurtigt det "bestående" på nakken; de havde problemer med at forklare sig udadtil (fordi det at skabe alternativer kræver, at alle kræfter anvendes indadtil); og de skabtes ofte på et urealistisk grundlag. I denne begyndelsesfase var forsøgene en legeplads for det ekstra og det nye, og det var adgangen til ressourcer for de, der havde mod og lyst (Adamsen og Fisker 1990, Adamsen 1992).

I slutningen af 1970'erne begyndte det offentlige at få øjnene op for potentialerne $\mathrm{i}$ forsøgsog udviklingsprojekter. På den ene side vakte forsøgene opmærksomhed og på den anden side var velfærdsstaten og samfundets indretning under kritik. Forskellige steder i centraladministrationen begyndte man at indsamle informationer om og registrere forskellige fors $\emptyset$, give konsulentbistand og yde økonomisk støtte om end i beskedent omfang (Hegland 1990). Under Undervisningsministeriet blev det første store offentlige forsøgsprogram etableret allerede i 1977 til bekæmpelse af ungdomsarbejdsløsheden (som senere udviklede sig til den egentlige daghøjskolebevægelse).

Fra begyndelsen af 1980'erne blev forsøgene en del af en udviklings- og omstillingsstrategi (Adamsen 1992). Da Ritt Bjerregaard i 1980 blev socialminister introducerede hun eksperimenter og nytænkning som et middel til opblødning i den etablerede forvaltningsstruktur og til at ændre den professionelle rolle hos social- og sundhedsarbejdere (Adamsen 1992), og samme år blev Socialstyrelsens forsøgsudvalg (SOFUS) oprettet. Da firkløverregeringen blev dannet i 1982 fulgte den nye socialminister, Palle Simonsen, det op med et ønske om et tættere

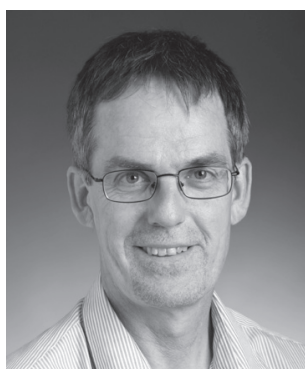

samarbejde mellem de frivillige organisationer og de centrale myndigheder, og samme år fik han indført en forsøgsparagraf i bistandsloven. Året efter blev "Kontaktudvalget til frivillige organisationer og sociale netværk" oprettet, bevillingerne til "SOFUS" blev forøget, og fra 1980-1988 bevilgedes ca. 60 millioner kr. fra Socialstyrelsens forsøgsudvalg. Samtidig støttede mange private fonde forsøg på det sociale område (Sygekassernes Helsefond og Egmont $H$. Petersens fond).

1980'erne var de store forsøgsprogrammers årti. Inden for folkeoplysningsområdet blev der igangsat et stort forsøgs- og udviklingsprogram, det såkaldte 10-punktsprogram, som fra 1985 til 1988 uddelte 110 millioner kr. til 448 lokale forsøgs- og udviklingsprojekter. Idéen med 10-punktsprogrammet var bl.a. at medvirke til opbygning af fællesskaber omkring familien, landsbyen eller bydelen. I 1987 blev et endnu større program til udvikling af folkeskolen, det såkaldte 7-punkts-program, iværksat - derunder også forsøg med skolen som lokalt kulturcenter. Fra dette program blev der fra 1987 til 1990 fordelt ca. 400 millioner kr. Begge programmer gav støtte til mange lokale idrætsprojekter. På det sociale området oprettedes Det sociale udviklingsprogram - SUM - der tog sigte på at forebygge sociale problemer ved bl.a. at styrke de lokale fællesskabers muligheder for at løse 
problemer i fællesskab ved at inddrage befolkningen i lokalområdet. Fra 1988 til 1991 brugte dette program ca. 350 millioner kr. på ca. 1600 forsøgs- og udviklingsprojekter.

Fælles for alle forsøgsprogrammerne var sigtet, at borgere i deres lokale miljøer skulle finde sammen om at gennemføre innovative forsøgsprojekter inden for en bred central styring (Qvortrup 1991). Det karakteriserede endvidere programmerne, at de blev evalueret, og evaluering blev generelt udviklet og institutionaliseret parallelt med forsøgsprogrammerne. For eksempel oprettedes Udviklingscenteret for Voksenundervisning og Folkeoplysning, der blev en af de varmeste fortalere for forsøgsstrategien.

\section{FORSøGS- OG UDVIKLINGSPROGRAMMER I IDRAETTEN}

Denne udvikling satte også sit præg på idrætspolitikken. I 1985 nedsatte daværende kulturminister Mimi Stilling Jakobsen et breddeidrætsudvalg, der bl.a. fik til opgave at

"overveje foranstaltninger, der kan forbedre vilkårene for de idrætsligt set dårligt stillede grupper af befolkningen, herunder mennesker - især ældre - uden særlig idrætserfaring, arbejdsledige og mennesker med skiftende arbejdstid, gæstearbejdere og unge med socialt vanskelige vilkår, samt mennesker, der bor i det indre af store byområder, handicappede og familien som samlet bruger."

Året efter kom udvalget med en betænkning, hvor man bl.a. foreslog, at

"der afsættes midler til en aktivitetspulje til udvikling, omstilling og forsøg, (for) at der gives mulighed for at nyskabe, ændre og udvikle fritidsvirksomhed, som er i overens- stemmelse med de lokale behov. Puljen skal således anvendes til såvel støtte for nye initiativtagere som til etablerede foreningers nytænkning” (Kulturministeriet 1987).

Hverken dette eller andre forslag blev fulgt op af konkrete ændringer i idrætspolitikken trods flere politiske initiativer. Idrætsorganisationerne var primært interesseret $\mathrm{i}$ flere penge, og dette ønske fik de opfyldt, da lotto blev indført i 1988. Det resulterede i en stærk forøgelse af den statslige støtte til organisationerne, som dog var betinget af, at pengene skulle anvendes til at styrke breddeidrætten. I bemærkningerne til loven blev det imidlertid præciseret, at idrætsorganisationerne skulle afsætte midler til forsøg og udvikling af breddeidrætten, og at andelen skulle fastlægges i samråd med Kulturministeriet.

Kulturministeriet har siden da brugt en del af ministeriets andel af tips- og lottooverskuddet til at oprette puljer til særlige formål. I 1995 var der således puljer for 'Udvikling, omstilling og forsøg', 'Idræt i storbyen' og 'Flygtninge og asylansøgere’' (Kulturministeriet 1996).

Det største og kendteste af disse forsøgs- og udviklingsprogrammer inden for idrætten er 'Det Idrætspolitiske Idéprogram' (IPIP), der blev oprettet i 1998. Af kommissoriet for programmet fremgik, at det var regeringens "udspil $i$ forhold til den brede, folkelige idræt og en udmøntning af de forslag, der i 1987 blev lagt frem i betænkningen om breddeidrætten i Danmark" (Kulturministeriet 1998).

Programmet var inspireret af modellen for uafhængige og sagkyndige "fonde", som dengang fandtes på en række områder af kulturlivet, og foreslået $\mathrm{i}$ den idrætspolitiske analyse 'Idrættens tredje vej'. Da Ebbe Lundgaard afløste Jytte Hilden som kulturminister i 1996 blev 
idéen ændret til et forslag om oprettelsen af en idrætspolitisk fond med i alt 100 mio. kr. om året, som skulle stå for iværksættelsen af nye initiativer på det idrætspolitiske område. Det lykkedes ikke Ebbe Lundgaard at realisere forslaget, men i 1998 formåede hans afløser som kulturminister, Elsebeth Gerner Nielsen, at få tilslutning til en mindre ambitiøs udgave af den foreslåede fond i udgave af Det Idrætspolitiske Idéprogram.

Formålet med programmet var at udvikle idrættens kulturpolitiske dimension og styrke mangfoldigheden, kvaliteten og ytringsfriheden i dansk idrætsliv. Programmet fik oprindelig stillet 75 millioner kr. til rådighed over en treårig periode fra august 1999 til udgangen af 2002. I begyndelsen af 2002 besluttede den nye VKregering imidlertid, at programmet skulle ophøre før forsøgsperiodens udløb. Officielt som et led i en sanering af råd, udvalg og programmer, men reelt for at behage idrætsorganisationerne, som ikke brød sig om den rolle, IPIP havde fået i idrætspolitikken. Efterfølgende bevilgede kulturminister Brian Mikkelsen 5 millioner kr. til afviklingen af programmet i løbet af 2002, så det samlede beløb til de mange projekter endte på 60 millioner $\mathrm{kr}$.

Selvom det overordnede formål med IPIP var at fremme den kulturpolitiske dimension i idrætten, så havde hver tredje af de støttede projekter sociale og sundhedsmæssige mål. 26 af de i alt 150 støttede projekter tog sigte på 'idræt og integration for børn, unge og voksne med anden etnisk baggrund', og 14 var målrettet 'idræt for idrætssvage/foreningsløse unge'. Det var bl.a. projekter med titler som 'Tarzan i Hobro', 'Motion og sundhed - en fed idé', 'projekt Kosovo', 'Indvandrere i foreninger i Aalborg', 'Streetsport' og ' Ishockey for muslimske piger' (Ibsen 2002).
Det karakteristiske for disse forsøgs- og ud viklingsprogrammer i 1980'erne og enkelte i 1990’erne var,

- at det var store og brede programmer, hvor man i højere grad lagde vægt på forsøg og nytænkning end fremme af specifikke mål,

- at udmøntningen af programmet, især fordelingen af midlerne, var overladt til et udvalg eller en komité, der i princippet var uafhængig af ministeriet (typisk bestående af eksperter på det pågældende område og repræsentanter for organisationer),

- at sigtet med programmet som regel var efterfølgende lovgivning og forvaltning på området (for eksempel tog 10-punktsprogrammet sigte på en ny lovgivning, der skulle erstatte Fritidsloven)

Derfor var store evalueringer også en integreret del af programmerne; det vil sige, at der blev afsat midler til evaluering af hele programmet.

\section{KOMMUNITARISTISK STYRINGSIDEAL}

Denne forsøgs- og udviklingspolitik med store forsøgsprogrammer var led i en betydelig decentralisering af den offentlige sektor. Dels ved at staten overlod en række opgaver til kommunerne, dels ved at de offentlige institutioner fik en betydelig selvbestemmelse, og visse opgaver blev overdraget til private og frivillige organisationer. Samtidig blev den statslige bureaukratiske regel- og detailregulering afløst af nye ledelses- og organiseringsprincipper. Decentralisering kan imidlertid tage forskellige former. Forsøgs- og udviklingsprogrammerne var led i et decentraliseringsideal, der kan betegnes som kommunitaristisk (afledt af det engelske ord for lokalsamfund: community) (Ståhlberg 1998). 
Det kommunitaristiske organiseringsideal er kollektivistisk orienteret, hvor de vigtigste styringsidealer er selvstyre og brugerdemokrati. ${ }^{1}$ Dette ideal ligger bl.a. bag indførelsen af skoleog institutionsbestyrelser, oprettelsen af beboerhuse, og det ligger bag de ovenfor beskrevne forsøgs- og udviklingsprogrammer i 1980'erne, der bl.a. tog sigte på at styrke de lokale fællesskaber.

Det kommunitaristiske organiseringsideal finder vi dog især i reglerne for den offentlige støtte til de frie skoler og folkeoplysningen, der giver borgerne mulighed for at etablere og tilslutte sig en forening, en aftenskole eller en fri skole i overensstemmelse med livssyn, pædagogiske idealer eller lokale traditioner og ønsker. En forudsætning for dette er, i henhold til dette ideal, at de fri organisationer - foreninger som institutioner - har en betydelig frihed til selv at bestemme, hvem der kan være medlem, hvilke værdier organisationen skal bygge på, hvilke metoder den vil anvende, hvordan den skal ledes, og hvordan pengene skal bruges.

I lovgivningen for støtte til kultur- og fritidsforeninger, i daglig tale benævnt som Folkeoplysningsloven, er dette princip udmøntet i en række bestemmelser om, at kommunen skal respektere den enkelte forenings egenart (dvs. dens aktiviteter, formål og idégrundlag), hvordan aktiviteterne tilrettelægges, hvem foreningen benytter som leder og instruktør, hvordan den kommunale støtte anvendes osv. (Folkeoplysningsloven). Inden for denne forståelse er det endvidere et centralt princip, at det er deltagerne selv (forældrekredsen i den frie skole, deltagerne på aftenskoleholdet og medlemmerne i foreningen), der så at sige evaluerer og kontrollerer, og derfor har man modsat sig bestræbelser på ekstern kontrol og evaluering efter eksternt fastlagte kvalitetsnormer.

\section{AENDRING I FORSØGS- OG UDVIKLINGSPOLITIKKEN}

Op gennem 1990'erne voksede de offentlige midler til udviklings- og forsøgsprogrammer. Mellem 1994 og 1997 administrerede Socialministeriet således puljer for i alt 1.374 millioner kr., altså betydeligt mere end der blev brugt på forsøgsprogrammerne i 1980'erne. De mange penge dertil kom fra den såkaldte Satsreguleringspulje, som består af et beløb, der tages fra overførselsindkomsterne (især det beløb der udbetales til pensionister), og i stedet anvendes på konkrete socialpolitiske tiltag for de samme grupper (personer på overførselsindkomster) (Bogason et al. 1995).

Men forsøgsstrategien ændrede karakter, så forsøgs- og projektmidlerne i højere grad tog sigte på at forbedre indsatsen på bestemte områder og at effektivisere den offentlige service. 1980'ernes store forsøgsprogrammer blev afløst af mere specifikke, afgrænsede og målrettede puljer.

Det samme er også sket i idrætspolitikken. Da IPIP blev nedlagt troede både DIF og DGI, at det nu var slut med forsøgspuljer. Men de blev slemt skuffede. I 2003 afsatte Kulturministeren 24 millioner kr. til programmet 'Børn og unge i bevægelse', som efter ansøgning blev fordelt til en række såkaldte 'fyrtårnsprojekter', hvor samarbejdet mellem idrætsforeninger, skoler og SFO'ere var i fokus.

I Integrationsministeriet oprettede man i 2006 en pulje på 3 millioner kr. til 'Unge nydanskeres deltagelse i idræts- og foreningslivet' og en pulje på 4 millioner kr. til 'Integration gennem deltagelse i idræts- og foreningslivet'. Socialministeriet var også på banen i 2005 - i samarbejde med Kulturministeriet - med en kampagne for at få flere ældre til at dyrke idræt og motion.

De samme to ministerier gik i 2005 sammen om en pulje til idræt for vanskeligt stillede børn 


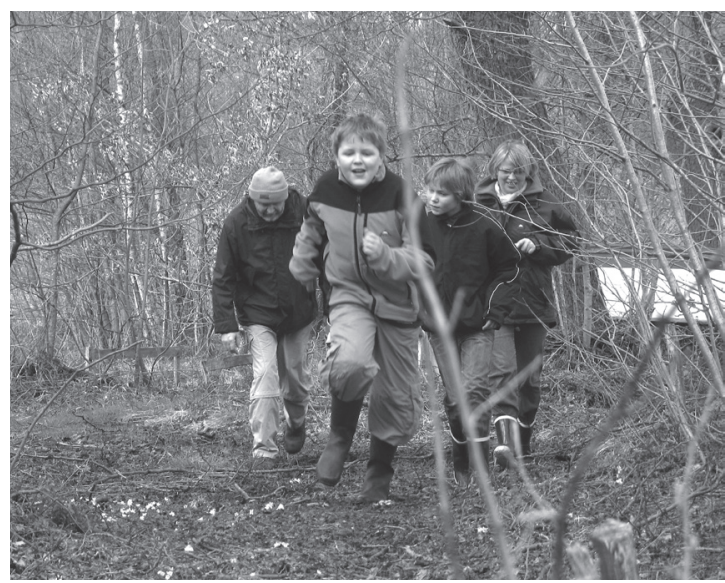

Billedet er fra et idræetsprojekt i Viborg for vanskeligt stillede, overvægtige børn, og indgår i Annette Michelsen la Cours Ph.d.afhandling fra 2010 om Idrætsforeningernes velfærdspotentiale. En sociologisk analyse af sammenhæengen mellem velfærdspolitik, social kapital og socialt entreprenørskab i 21 idræetsprojekter for vanskeligt stillede børn. (Fotograf Lone Simonsen)

på i alt 40 millioner kr. Formålet med puljen var at 'sikre, at vanskeligt stillede børn i højere grad involveres i idrætsforeningernes tilbud'.

I 2009 oprettede Kulturministeriet med støtte fra Nordea-fonden en pulje til breddeidrætskommuner på i alt 20 mio. kr. Puljens formål var i 2010 og 2011 at afprøve Breddeidrætsudvalgets forslag til fremme af idræt for alle. $36 \mathrm{kom}$ muner søgte om at komme i betragtning, men kun syv fik en bevilling.

Den seneste pulje, der blev annonceret i juni 2012, er en pulje under Social- og Integrationsministeriet til 'Idræt for udsatte grupper' på i alt 20 millioner kr. Formålet med puljen er at fremme, at idræt for socialt udsatte bliver en del af idrætsforeningernes tilbud i stedet for at være aktiviteter isoleret fra det almindelige foreningsliv (pressemeddelelse fra Social- og Integrationsministeriet den 20. juni 2012).
I et notat til breddeidrætsudvalgets rapport 'Idræt for alle', der blev offentliggjort i 2009, blev den samlede statslige støtte til statsadministrerede idrætsrelaterede puljer opgjort til 60 millioner kr. i 2008, hvoraf hovedparten var finansieret af satspuljemidler. Dertil kommer en række puljer, som ikke primært tog sigte på idræt, men som også kunne søges til idrætsformål (Kulturministeriet 2009, s. 446-450).

Forsøgs- og udviklingstankegangen smittede også af på lovgivningen. I flere love er der indført en forsøgsparagraf. Det gjaldt bl.a. Folkeoplysningsloven, som i 1991 afløste Fritidsloven, hvor den såkaldte 5 pct. pulje blev indført. Af de samlede midler til støtte af folkeoplysning skulle mindst 5 pct. gå til forsøg og udvikling, som foreninger og aftenskoler kunne søge om støtte fra til nye aktiviteter og projekter. Paragraffen blev indført som en følge af erfaringerne med 10-punktsprogrammet (beskrevet ovenfor). Selvom 5 pct. puljen er afskaffet, er kommunerne stadig forpligtet til at afsætte et beløb til udviklingsarbejde inden for folkeoplysningsområdet, og mange kommuner har deciderede forsøgspuljer, som foreningerne kan søge om støtte fra.

Idrætsorganisationerne lod sig også inspirere af forsøgs- og puljestrategien. DGI havde i en periode en 'Aktivitetspulje for lokalforeningerne' og en 'Prøv selv pulje til børn og unge', mens DIF inviterede idrætsforeningerne til at søge om støtte fra den såkaldte 'UFO-pulje' og fra mere specifikke puljer til minisport, idræt for flygtninge mv. Siden er disse puljer forsvundet og afløst af centralt bestemte udviklingsprojekter, som ansatte i organisationerne står for. Samtidig har organisationerne i stigende grad indrettet sig på at få del i de centrale puljer. For eksempel har DGI organiseret sig derefter med en særlige afdeling for forsøg og projekter, DGI Lab, og landsdelsforeningerne måles bl.a. på, 
hvor mange penge de henter ind fra fonde, kommuner og statslige puljer.

Denne anden bølge i forsøgs- og udviklingspolitikken adskiller sig fra de store forsøgs- og udviklingsprogrammer ved at den enkelte pulje

- er meget mindre end de store puljer fra 1980'erne (ofte få millioner kr. men i nogle tilfælde dog helt op til et halvt hundrede millioner kr.)

- tager sigte på at realisere centralt bestemte mål

- lægger mindre vægt på 'forsøg' og mere vægt på at 'udvikle området' (til det som staten ønsker)
- administreres i ministeriet, hvor fordelingen af pengene også typisk sker

- ikke tager sigte på efterfølgende lovgivning, og

- ofte ikke evalueres overordnet, dvs. at der primært stilles krav om, at projekterne kan dokumentere, hvad de har gjort for pengene, og kun hvis de selv ønsker det, gennemføres en egentlig evaluering af projektets virkning. I nogle tilfælde er der gennemført overordnede evalueringer, man da som regel ved en opsamling på projekternes erfaringsopsamlinger og dokumentationer for projektets forløb.

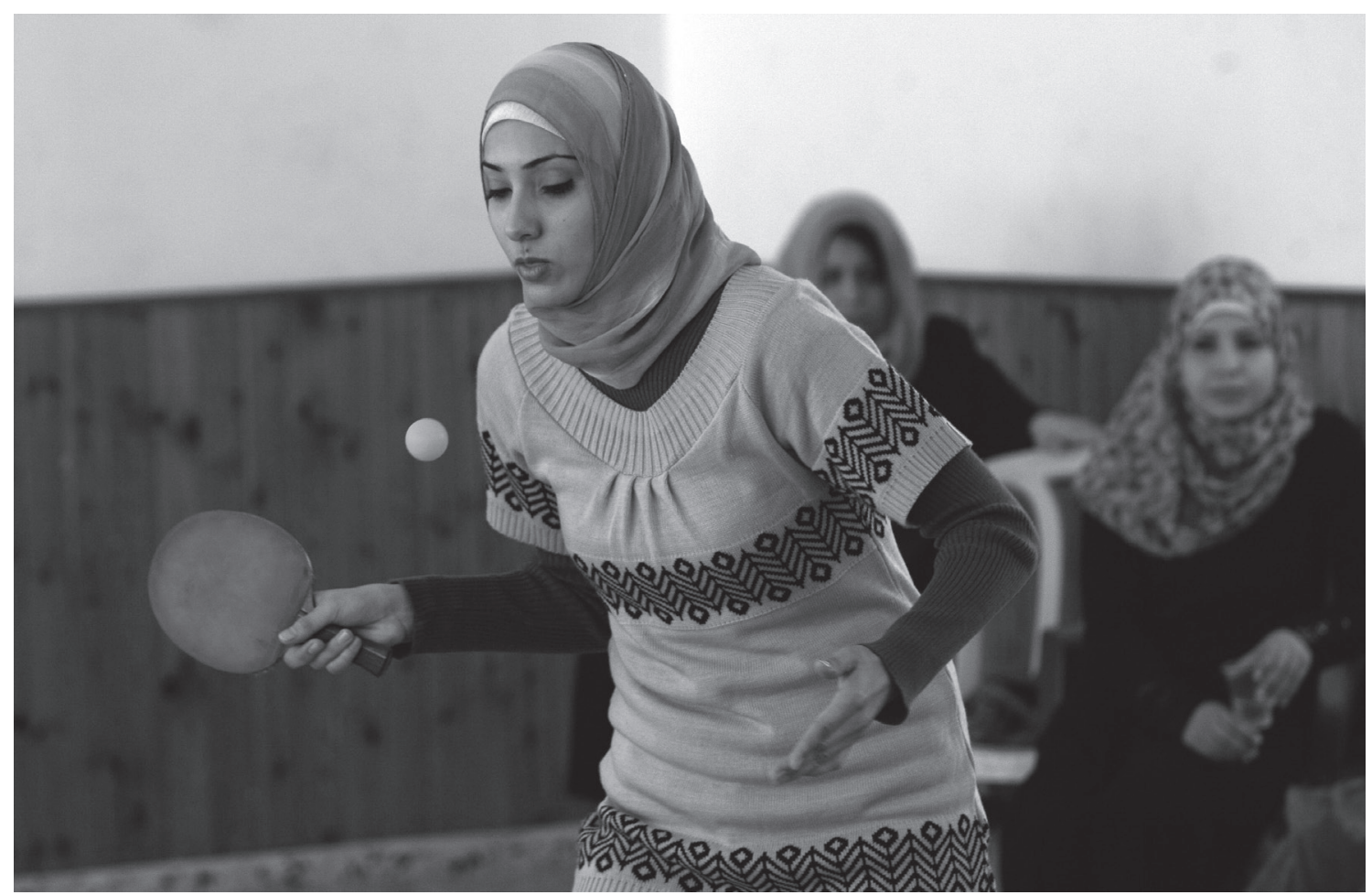

Muslimske kvinder spiller bordtennis (Foto: Scanpix/Mahmud Hams) 


\section{NY FORM FOR STATSLIG DECENTRALISERING: NEW PUBLIC MANAGEMENT}

Denne ændring i pulje- og projektpolitikken igennem de seneste tyve år er præget af mere liberale og økonomisk orienterede styringsidealer i det offentlige. I daglig tale benævnt som New Public Management. NPM tager udgangspunkt i en kritik af den traditionelle offentlige sektor for at være for centralistisk, bureaukratisk og ineffektiv, dvs. det er i princippet også en reaktion på centralisme $\mathrm{i}$ gammeldags forstand. I stedet tilstræber NPM - når den fremlægges af sine fortalere - en fleksibel, resultatorienteret og omkostningseffektiv offentlig sektor. Der er tale om en ny tænkemåde, som fra slutningen af 1980'erne bredte sig til hovedparten af den offentlige sektor, og de relationer den har med private og frivillige aktører (Selle 2001, s. 175, Wijkström et al. 2004). Ud fra denne tankegang er det mindre afgørende, hvem der står for opgaven, hvis kvalitet (defineret af det offentlige) og pris er i orden i sammenligning med andre, der byder sig til. Dette indebærer bl.a.,

- at den traditionelle centraliserede organisering og opgavevaretagelse erstattes af eller suppleres med decentralisering, privatisering, udlicitering, kontraktstyring og konkurrence på ydelser mellem offentlige udbydere, private firmaer og frivillige, nonprofit organisationer,

- at brugerne får mulighed for at vælge - og fravælge - mellem alternative valgmuligheder, så demokratisk kontrol erstattes af markedskontrol, og

- at regel- og detailstyring erstattes af mål- og resultatorientering efter eksplicitte standarder og kvantitative indikatorer (Klausen \& Ståhlberg 1998).
I Danmark har NPM primært vundet indpas i den måde, som den offentlige sektor selv tager sig af, organiserer og styrer offentlige institutioner, mens egentlig privatisering med privat finansiering af tjenesteydelser samt udlicitering af opgaver, som det offentlige har ansvaret for og derfor også finansierer, kun i mindre omfang er slået igennem. Ændringerne i forsøgs- og udviklingspuljerne kan imidlertid ses som en konsekvens af NPM-idealerne.

Inden for denne fortolkning af hensigten med forsøgs- og udviklingspuljerne er der altså tale om en decentralisering. Men ser man nærmere på programmerne og deres styring kan man også tolke pulje- og projektpolitikken som en ny form for central styring (Qvortrup 1991). Formelt initieres og ledes projekterne decentralt, men samtidig opretholdes en stærk central styring:

- Ansøgningerne om økonomisk støtte er ofte ekkoer af centrale bureaukraters formuleringer.

- En lille gruppe bestemmer, hvem der skal have støtte.

- Den hidtidige regelstyrede kontrol er erstattet af en central evaluering.

Ud fra denne synsvinkel er strategien et blødt statsligt styringsredskab på politikområder, der er overladt til kommunerne og organisationerne uden specifikke anvisninger på, hvordan målene skal opnås, dvs. det centrale statslige niveaus forsøg på at påvirke kommunerne og andre aktører, så den lokale udmøntning af politikken stemmer overens med landspolitiske mål.

De styringsmæssige potentialer i forsøgs- og udviklingspuljerne ligger dels i de økonomiske incitamenter dels i signalværdien af programmet. Målt i kroner og ører er disse programmers betydning marginale, selvom de kan have stor 
betydning på specifikke områder. Programmernes væsentligste betydning er givetvis deres indvirkning på den faglige og politisk-ideologiske diskurs, og det er måske grunden til, at der ofte er så meget fokus på disse programmer selvom de økonomisk fylder så lidt i det samlede regnskab (Anker et al. 2001).

\section{HVILIKEN BETYDNING HAR PROJEKTERNE?}

Hvilken betydning har forsøgs- og udviklingsprogrammer og de mange projekter haft for idrætten? Er de idrætssvage grupper blevet mere idrætsaktive? Har projekterne givet inspiration til nye metoder og organiseringsformer? Har nye koncepter for tilrettelæggelsen og organiseringen af idrætsaktiviteter vundet indpas? Har erfaringerne fra projekterne resulteret i ny lovgivning? Har de mange forsøg skabt en ny diskurs for idrætten og idrætspolitikken? Det ved vi ikke ret meget om, men et forskningsprojekt på Center for forskning i Idræt, Sundhed og Civilsamfund på Syddansk Universitet forsøger at kaste lys over nogle af disse spørgsmål.

I det følgende vil jeg nøjes med at samle op på, hvad en række evalueringer af forsøgs- og udviklingsprogrammer samt projekter inden for idrætten viser. De seneste ti år har forfatteren til denne artikel haft ansvaret for evalueringen af flere idrætspuljer, bl.a. evalueringen af Idrætspolitisk Idéprogram (Ibsen 2002) og evalueringen af puljen til idræt for vanskeligt stillede børn (Ibsen et al. 2012), samt en række projekter hvoraf de fleste var finansieret af en forsøgs- og udviklingspulje. Bortset fra Idrætspolitisk Idéprogram har alle puljer og projekter taget sigte på at fremme fysisk aktivitet for fysisk inaktive børn eller voksne eller fremme deltagelse i idræt for socialt udsatte eller vanskeligt stillede børn og unge. Det karakteriserer også de fleste af de evaluerede projekter, at de har haft som formål at fremme et samarbejde (partnerskab) mellem idrætsforeninger og kommunale institutioner. Som bilag til denne artikel findes en oversigt over de forsøgs- og udviklingsprogrammer og de projekter, som analysen bygger på. Omfanget af denne artikel tillader ikke en større analyse af, hvad disse evalueringer har lært os om puljer og projekter. Jeg vil derfor nøjes med at trække nogle af de konklusioner op, som går igen i de fleste af evalueringerne.

For det første lykkes det sjældent for projekterne at nå de opstillede mål for rekruttering af fysisk inaktive, overvægtige, socialt udsatte eller anden målgruppe, som projektet er målrettet. Mange af projekterne får en pæn tilslutning, men det er ofte børn eller voksne, der ikke tilhører den målgruppe, projektet primært tog sigte på. I moderne projekt-management gør man meget ud af at opstille mål og succeskriterier. Det er sjældent, at projekterne opfylder disse kriterier for et succesfuldt projekt.

For det andet er det svært at påvise, at målgruppen (for eksempel fysisk inaktive og svært overvægtige) har opnået en væsentlig effekt af deltagelsen i de fysiske aktiviteter (for eksempel øget fysisk aktivitet, vægttab mv.). Det skal dog siges, at det er ganske få af de evaluerede projekter, hvor dette er undersøgt på en pålidelig måde (for eksempel ved fysiske test eller objektive målinger af fysisk aktivitetsniveau).

For det tredje stopper mange af projekterne, når bevillingen fra den statslige pulje, fonden eller en anden ekstern kilde hører op, og erfaringerne fra projektet forsvinder hurtigt. Projekterne er i de fleste tilfælde så afhængige af en betydelig ekstern støtte, at de kun fortsætter, hvis det lykkes at få projektet integreret i den almindelige drift i foreningen, organisationen eller kommunen, eller det lykkes at skaffe en ny bevilling fra ekstern side. Og det sker meget sjældent. 
For det fjerde kommer det tilstræbte partnerskab mellem idrætsforeninger og kommunale institutioner, som har kendetegnet de fleste af de evaluerede projekter, sjældent til at fungere som tilstræbt. Det er især svært at skabe et ligeværdigt samarbejde mellem de forskellige foreninger og institutioner. I nogle tilfælde svigter rollefordelingen (for eksempel når kommunale institutioner ikke formår at rekruttere overvægtige børn til de hold, som idrætsforeninger har oprettet (se evalueringen af det fynske projekt Grib Chancen)). I andre tilfælde får foreningerne en sekundær rolle i aktiviteter, der foregår på skolen eller SFOen (se bl.a. evalueringen af projekt Skolesport). Og som regel bliver partnerskabet ikke en integreret og prioriteret del af foreningen, institutionen eller kommunen. Det lever i kraft af enkelte personers engagement deri, og eksisterer så længe, der er ekstra midler til samarbejdet. De overordnede mål for projekterne svarer ofte ikke til foreningernes mål og selvforståelse. Projektet eksisterer så at sige i yderkanten af 'moder-organisationen', men er ofte ikke prioriteret særligt højt, og er kun 'tålt', så længe det ikke koster organisationen noget.

Men selvom de fleste af projekterne ikke lever op til egne mål og succeskriterier, vurderer såvel 'projekt-ejerne' som deltagerne som regel projektet meget positivt. Selv i tilfælde hvor projektet nærmest har været en fiasko.

Der er flere mulige forklaringer på, at projekterne har vanskeligt ved at opnå sine mål. En plausibel forklaring er, at projekterne tager sigte på at rekruttere børn og voksne, som er mindre fysisk aktive og dyrker mindre idræt end befolkningen i gennemsnit gør, og det er derfor i mange tilfælde en meget større opgave at gøre disse grupper interesseret i idræt.

Derfor er målene og succeskriterierne, som projekterne opstiller i ansøgningen, ofte urea- listiske. Dels fordi ansøgerne undervurderer vanskelighederne ved at rekruttere idrætssvage og motionsuvante grupper. Dels fordi ambitiøse mål gør projektet mere interessant for dem, der deler pengene ud. En projektejer fortalte under en samtale om projektet, at ministeriet, som organisationen søgte om penge fra til et projekt, havde bedt ansøgeren om at forhøje de forventede mål for projektet, hvis de skulle gøre sig håb om at få en bevilling.

Men projekterne har også svært ved at leve op til egne og andres forventninger, fordi de som regel er for små og for kortvarige til at få en væsentlig effekt. Projekter får typisk en bevilling for et til maksimalt tre år. Det tager ofte tid, at få nye organiseringsformer (for eksempel samarbejde mellem en forening og en kommunal institution) til at fungere; at få kontakt til og tillid fra den målgruppe, som projektet er rettet mod; og at få aktiviteterne for målgruppen til at fungere, så deltagerne har lyst til at fortsætte. Derfor er det også et problem, at der efter alt at dømme sker så lille en overføring af erfaringer fra tidligere projekter til nye projekter, som kunne have hjulpet dem til en bedre start. Flere af de evaluerede projekter ligner til forveksling hinanden, men i flere tilfælde kendte de involverede i det nye projekt knap nok et tilsvarende projekt, selvom det blev afsluttet få år inden.

\section{FORSIKNING I 'NATURLIGE EISSPERIMENTER'}

Det er som nævnt en integreret del af pulje- og projekt-konceptet, at projekterne skal evalueres. Det var det før evaluering for alvor vandt indpas $\mathrm{i}$ den offentlige forvaltning. I de store forsøgs- og udviklingsprogrammer i 1980'erne og 1990'erne gik evalueringerne ud på at blive klogere på, hvad man havde lært af de mange 'alternativer': nye aktiviteter, nye metoder og nye organiseringsformer. I den anden bølge af 
mere målrettede puljer og derunder hørende projekter, har formålet i højere grad været at undersøge, om projektet levede op til sine succeskriterier, dvs. nåede sine mål.

Desværre er udbyttet af de mange evalueringer af de seneste ti års puljer og projekter ofte alt for lille. Det skyldes bl.a., at ministerierne, som administrerer disse puljer, ikke tillægger evaluering større betydning. Og det har måske baggrund i det forhold, at politikerne ikke ønsker at afsætte midler dertil. Derfor overlades det ofte til projekterne, som puljen har støttet, selv at evaluere projektet eller at rekvirere en ekstern evaluator til opgaven. I nogle tilfælde samles der efter puljens afslutning op på de forskellige erfaringer og evalueringer af de forskellige puljer. Men der er sjældent en overordnet evalueringsstrategi for puljen.

De samlede ressourcer, der bruges på evaluering af de forskellige projekter i en pulje, vil som regel være rigeligt til en grundig undersøgelse, men midlerne dertil bruges ganske enkelt forkert på en række forholdsvis små og ukoordinerede evalueringer af de forskellige projekter, som det er vanskeligt efterfølgende at benytte til en samlet evaluering af de mange projekter.

Mange af evalueringerne lægger endvidere for meget vægt på at måle 'effekt' på bekostning af de pædagogiske, kulturelle og organisatoriske sider af projektet, der kan bidrage til at forklare, hvorfor nogle projekter lykkes, mens andre ikke gør. Effektanalyserne er endvidere mangelfulde, fordi de af ressourcemæssige grunde som regel bygger på selvrapportering fra deltagerne.

Der gennemføres stort set heller ikke undersøgelser af den langvarige virkning af en pulje eller et projekt, selvom forankring af de igangsatte aktiviteter tillægges stor betydning i formålet for puljerne. For eksempel om en gruppe af fysisk inaktive, der er kommet $\mathrm{i}$ gang med motion i et nyt projekt, fortsat er fysisk aktive to år efter, at projektet stoppede. Og man har heller ikke interesseret sig for, i hvilken grad et forsøgs- og udviklingsprogram eller et vellykket projekt har skabt 'ringe $i$ vandet' $i$ form af nye aktiviteter, metoder, organiseringsformer og diskurser på området. I det hele taget bliver disse programmer og projekter sjældent analyseret ud fra en kulturanalytiske, organisationssociologisk eller politologisk synsvinkel.

Endelig foretages der meget sjældent systematiske komparative analyser af projekterne og deres virkning. Derfor er det vanskeligt at vurdere effekten eller betydningen af forskellige aktiviteter, metoder eller organiseringsformer, dvs. om en type af indsats er bedre eller dårligere end andre typer af indsatser.

Forsøgs- og udviklingsprojekter - når de er bedst - kan betragtes som 'naturlige eksperimenter' til forskel fra de mere designede interventioner, som er blevet et ideal i dele af forskningen. I dag gennemføres meget interventionsforskning, som opfylder mange idealer for god forskning, men som alligevel ofte ikke fører til ret meget nyt. Bl.a. fordi interventionerne ofte er velkendte og afprøvede (forskerne foretrækker som regel interventioner, som med stor sandsynlighed har en effekt), og fordi de store og nytænkende interventioner kræver mange penge, som det er svært at få finansieret som led i forskning. Omvendt findes en masse spændende 'naturlige eksperimenter' i de mange projekter, som statslige puljer og private fonde støtter, men som desværre sjældent bliver undersøgt særligt grundigt. Kvalificeret forskning i samfundsmæssige 'naturlige' eksperimenter, som forsøgs- og udviklingsprogrammer i bedste fald er, kunne være meget mere værdifuld end den traditionelle interventionsforskning.

På Realdanias konference om 'Civilsamfun- 
dets filantropiske stemmer' den 21. maj 2012 fremlagde Mattthew Bishop, der er erhvervsredaktør på The Economist, det synspunkt, at de store fonde i højere grad end det offentlige er $\mathrm{i}$ stand til at støtte nye, ikke-afprøvede og 'risikable' løsninger på samfundets problemer. De løsninger, der bliver en succes, kan så overtages af det offentlige. Det er bl.a. den rolle som fonde som Lokale- og Anlægsfonden og Realdania har inden for kultur- og idrætsfaciliteter, de fysiske rum samt byudvikling. Samme rolle burde forsøgs- og udviklingsprogrammerne i højere grad have. Men det forudsætter selvfølgelig, at der forskes i dem på en meget grundige måde, end de mange små evalueringer giver mulighed for.

\section{AFSLUTNING}

Forsøgs- og udviklingsudviklingsprogrammerne opstod som en reaktion på centralisme og ekspertstyre $\mathrm{i}$ en tid, hvor det sprudlede med alternativer i det civile samfund. Det var - i retorikken i det mindste - et skifte fra 'top down' til 'bottom up', som man i dag vil udtrykke det. Forsøgs- og udviklingspuljerne er en blanding af såvel en 'fra neden' tendens og en 'fra oven' tendens: De alternative og skæver ideer, nye initiativer og tværgående projekter, der i 1960'erne og 1970'erne spirede frem 'fra neden', blev i 1980'erne hjulpet på vej af en modernisering af den offentlige sektor med effektivisering, rammestyring, afbureaukratisering, privatisering, iværksætterstimulering, selvforvaltning og decentralisering. Forsøgsprogrammerne blev en ny form for 'blød' styring, da den centrale planstyring smuldrede.

Men i takt med at programmerne og puljerne er blevet mindre, mere målrettede og kortvarige har de mistet deres væsentligste værdi: at støtte eksperimenter og at afsøge alternative løsninger på samfundets udfordringer. I stedet er pul- jerne blevet politiske markeringer på områder, hvor der ikke er politisk vilje til for alvor at gøre noget. Man har nu i mere end 15 år oprettet den ene pulje efter den anden til fremme af idræt for grupper, der ikke er idrætsaktive, uden et eneste forsøg på at omsætte erfaringerne fra disse mange forsøg i lovgivning.

På den ene side er der behov for, at der i højere grad gives mulighed for at eksperimentere. På den anden side må det kombineres med et mere bevidst politisk sigte med forsøgs- og udviklingsprogrammerne, dvs. en mere systematisk forskning i disse eksperimenter og en plan for, hvordan disse kan bruges i en udvikling af politikken på det pågældende samfundsområde.

\section{LITTERATURLISTE}

Adamsen, L. \& Fisker, J. (1989). "Forsøg og tværgående analyser”. I: Bøgh, C. \& Olsen, C.B. Lokalsamfundsforskning - tendenser og perspektiver. SIKON, 1989.

Adamsen L. \& Hertz. E. (1992). Selvhjcelpsgrupper indenfor SUM-programmet og tilgraensende områder: En sammenfatning af forskningsmassige resultater. Kbh.: Akademisk Forlag.

Anker, J., Munk A., Koch-Nielsen, I. og Raun, M. (2001). De sociale puljer - en tvargående analyse af Socialministeriets puljemidler. København: Socialforskningsinstituttet.

Bogason, P., Friis, C. S., Hulgård, L., Rasmussen, E., Sehested, K., Smed, J., Sørensen, E. (1995). "Kommunalt demokrati - set fra neden". I: Kommunernes Jubilaeumsfond: Perspektiver for kommunestyrets udvikling. Prisvinderne i kommunernes jubilæumsfonds priskonkurrence om det lokale demokrati. København: Kommuneinformation. 
Etzioni. Amitai (1988). The Moral Dimension. Toward A New Economics. The Free Press.

Etzioni, A. (red.) (1995). New Communitarian thinking. Persons, Virtues, Institutions and Communities. Charlotteville and London: Lawrence \& Wishart.

Hegland, T.J. (1990). "SUM-programmet. En historisk-sociologisk baggrundsanalyse". I SUMsummarum. Tidsskrift for social udvikling. Nr. 1. 1990.

Ibsen, Bjarne (2002). Evaluering af Det Idraetspolitiske Idéprogram. København: Institut for Idræt. Københavns Universitet, og Institut for Forskning i Idræt og Folkelig Oplysning.

Ibsen, B. \& Eichberg, H. (2012). "Dansk idrætspolitik. Mellem frivillighed og statslig styring". I: Eichberg. H. Idrcetspolitik $i$ komparativ belysning - national og international. Syddansk Universitetsforlag.

Ibsen, B., Jespersen, E.; Støckel, J.T., Fehsenfeld, M. \& Nielsen, L.B. ( 2012). Idroettens outsidere Inklusion eller eksklusion af vanskeligt stillede børn og unge $i$ idrcet. Evaluering af puljen til idraet for vanskeligt stillede børn og unge. Movements 2012: 9. Institut for Idræt og Biomekanik. Odense: Syddansk Universitet.

Klausen, K.K. \& Ståhlberg, K. (1998). New Public Management $i$ Norden. Nye organisations- og ledelsesformer $i$ den decentrale velfardsstat. Odense: Odense Universitetsforlag.

Kulturministeriet (1987). Betcenkning om breddeidratten i Danmark: Betænkning fra Kulturministeriets Breddeidrætsudvalg. Betænkning nr. 1094.
Kulturministeriet (1996). Idrcettens tipsmidler, bind 1 og bind 2 .

Kulturministeriet (1998). Kommissorium Idraetspolitisk Idéprogram.

Kulturministeriet (2009). Idraet for alle. Breddeidratsudvalgets rapport - baggrund og analyse.

Qvortrup, L. (1991). Kedsomhedens tidsalder. Odense: Odense Universitetsforlag.

Selle, P. (2001). "Privatisering som tidsskel?" I: Henriksen, L.S. og Ibsen, B. (red.). Frivillighedens udfordringer - nordisk forskning om frivilligt arbejde og frivillige organisationer. Odense: Odense Universitetsforlag.

Ståhlberg, K. (1998). "Utvecklingspolitiken i finländska kommuner. Vad, var och vem?" I: Klausen, K.K. \& Ståhlberg, K.. New Public Management $i$ Norden. Nye organisations- og ledelsesformer $i$ den decentrale velfardsstat. Odense: Odense Universitetsforlag.

Wijkström, F.; Einarsson, S. og Larsson, O. (2004). Staten och det civila samhället. Idétraditioner och tankemodeller $i$ den statliga bidragsgivningen till ideella organisationer. Socialstyrelsen og Handelshögskolan i Stockholm.

Wolfe, A. (1989). Whose Keeper? Social Science and Moral Obligation. University of California Press. 
Bilag: Forsøgs- og udviklingsprogrammer og projekter, som Center for forskning i Idræt, Sundhed og Civilsamfund har evalueret

\begin{tabular}{|c|c|}
\hline Puljer & Evalueringsrapport \\
\hline $\begin{array}{l}\text { Idrætspolitisk Idéprogram. } \\
\text { Kulturministeriet }\end{array}$ & $\begin{array}{l}\text { Bjarne Ibsen (2002). Evaluering af Det Idrætspolitiske Idéprogram. } \\
\text { Institut for Idræt, Københavns Universitet, og Institut for } \\
\text { Forskning i Idræt og Folkelig Oplysning. }\end{array}$ \\
\hline $\begin{array}{l}\text { Puljen til idræt for vanskeligt } \\
\text { stillede børn. } \\
\text { Kulturministeriet }\end{array}$ & $\begin{array}{l}\text { Bjarne Iben, Ejgil Jespersen, Jan Toftegaard Støckel, Michael } \\
\text { Fehsenfeld og Louise Bæk Nielsen (2012). Idrættens outsidere - } \\
\text { Inklusion eller eksklusion af vanskeligt stillede børn og unge i } \\
\text { idræt. Evaluering af puljen til idræt for vanskeligt stillede børn og } \\
\text { unge. Movements 2012: x. Institut for Idræt og Biomekanik. } \\
\text { Syddansk Universitet }\end{array}$ \\
\hline \multicolumn{2}{|l|}{ Projekter } \\
\hline $\begin{array}{l}\text { Motion og Kost på Recept i } \\
\text { Københavns Kommune }\end{array}$ & $\begin{array}{l}\text { Roessler, Kirsten Kaya; Bjarne Ibsen; Bengt Saltin and Jan } \\
\text { Sørensen (2007). Fysisk aktivitet som behandling. Motion og Kost } \\
\text { på Recept i Københavns Kommune. Syddansk Universitetsforlag. }\end{array}$ \\
\hline Gå i Gang. DGI. & $\begin{array}{l}\text { Karsten Østerlund (2010). Gå i Gang. Slutevaluering. Movements } \\
\text { 2010:4. Institut for Idræt og Biomekanik. Syddansk Universitet. }\end{array}$ \\
\hline $\begin{array}{l}\text { København - en by i } \\
\text { bevægelse. Københavns } \\
\text { Kommune. }\end{array}$ & $\begin{array}{l}\text { Lise Specht Petersen og Bjarne Ibsen (2009). København - En by i } \\
\text { bevægelse. Evaluering af Københavns Kommunes motionsstrategi. } \\
\text { Movements 2009:7. Institut for Idræt og Biomekanik. Syddansk } \\
\text { Universitet. }\end{array}$ \\
\hline $\begin{array}{l}\text { Modelprojektet børn og unge } \\
\text { i bevægelse i Fyns Amt. DGI } \\
\text { Fyn. }\end{array}$ & $\begin{array}{l}\text { Jan Toftegaard Støckel (red.) (2008). Parallel leg eller integreret } \\
\text { leg. Partnerskaber om børn, leg og bevægelse. Evalueringsrapport. } \\
\text { Movements 2008: 2. Institut for Idræt og Biomekanik. Syddansk } \\
\text { Universitet. }\end{array}$ \\
\hline $\begin{array}{l}\text { Børn og bevægelse på } \\
\text { Bornholm. DGI Bornholm. }\end{array}$ & $\begin{array}{l}\text { Støckel, Jan Toftegaard (2007). Rapport for evaluering af } \\
\text { 'Modelprojekt børn og unge i bevægelse på Bornholm'. Center for } \\
\text { Forskning i Idræt, Sundhed og Civilsamfund. Syddansk } \\
\text { Universitet. }\end{array}$ \\
\hline $\begin{array}{l}\text { Fritid til bevægelse. Århus } \\
\text { Kommune. }\end{array}$ & $\begin{array}{l}\text { Malene Thøgersen (2006). Fritid til bevægelse. Evalueringsrapport. } \\
\text { Center for Forskning i Idræt, Sundhed og Civilsamfund. Syddansk } \\
\text { Universitet. }\end{array}$ \\
\hline
\end{tabular}




\begin{tabular}{|c|c|}
\hline $\begin{array}{l}\text { Rend og Hop - Vi si'r stop. } \\
\text { Varde Kommune. }\end{array}$ & $\begin{array}{l}\text { Ole Lund (2009). Rend og Hop - Vi si’r stop. Et sundhedsprojekts } \\
\text { bestræbelser på at skabe bedre betingelser for det sunde liv i } \\
\text { Varde Kommune. Evalueringsrapport. Movements 2009: 1. Institut } \\
\text { for Idræt og Biomekanik. Syddansk Universitet. }\end{array}$ \\
\hline $\begin{array}{l}\text { Sunde vaner fra barnsben. } \\
\text { Vejle Kommune }\end{array}$ & $\begin{array}{l}\text { Pernille Andreassen (2010). Evaluering af 'Sunde vaner fra } \\
\text { barnsben'. Movements 2010: 7. Institut for Idræt og Biomekanik. } \\
\text { Syddansk Universitet. }\end{array}$ \\
\hline Multiminen. Greve Kommune. & $\begin{array}{l}\text { Thomas Gjelstrup Bredahl (2012). Slutevaluering af Greve } \\
\text { Kommunes udviklingsprojekt 'Multiminen'. Movements 2012: } 1 . \\
\text { Institut for Idræt og Biomekanik. Syddansk Universitet. }\end{array}$ \\
\hline $\begin{array}{l}\text { Grib Chancen. Idrætspolitisk } \\
\text { Forum Fyn. }\end{array}$ & $\begin{array}{l}\text { Bjarne Ibsen, Louise Kamuk Storm og Simon Madsen (2012). } \\
\text { Evaluering af projekt Grib Chancen. Movements 2012: 13. Institut } \\
\text { for Idræt og Biomekanik. Syddansk Universitet. }\end{array}$ \\
\hline $\begin{array}{l}\text { Go Active. DGI Byens børne- } \\
\text { og ungeprojekt. }\end{array}$ & $\begin{array}{l}\text { Bjarne Ibsen (red.). Go Active - Større tilgængelighed til idræt for } \\
\text { børn på Vesterbro. Movements 2010: x. Institut for Idræt og } \\
\text { Biomekanik. Syddansk Universitet. }\end{array}$ \\
\hline $\begin{array}{l}\text { Bevæg dig sund og glad. } \\
\text { Esbjerg Kommune }\end{array}$ & $\begin{array}{l}\text { Louise Kamuk Storm, Simon Madsen og Bjarne Ibsen (2011). } \\
\text { Evaluering af 'Bevæg dig sund og glad'. Movements 2011: } 5 . \\
\text { Institut for Idræt og Biomekanik. Syddansk Universitet. }\end{array}$ \\
\hline $\begin{array}{l}\text { Skolesport. Dansk Skoleidræt, } \\
\text { DIF og TrygFonden. }\end{array}$ & $\begin{array}{l}\text { Rasmus Bergmann og Jan Toftegaard Støckel (2012). Skolesport } \\
\text { - organiseringen af et bæredygtigt bevægelseskoncept. Movements } \\
\text { 2010: x. Institut for Idræt og Biomekanik. Syddansk Universitet. }\end{array}$ \\
\hline
\end{tabular}

\section{NOTER}

1 Det kommunitaristiske samfundsideal er selvbestemmende fællesskaber baseret på stærke moralsk bånd. Dette samfundsideal blev formuleret i USA i 1980'erne som en reaktion mod og en stærk kritik af såvel den rettighedsbaserede velfærdspolitik som dens liberalistiske modsætning (se bl.a. Wolfe, 1989 og Etzioni, 1988 og 1995). 